\title{
"A ESCRAVIDÃO ESTÁ CONDENADA PELA RELIGIÃO": CATÓLICOS E PRESBITERIANOS NO CONTEXTO DA ABOLIÇÃO (MINAS GERAIS, 1886-1888)
}

"Slavery is Condemned by Religion": Catholics and

Presbyterians in the Context of the Abolition of Slavery (Minas

Gerais, 1886-1888)

"La esclavitud está condenada por la religión": católicos y presbiterianos en el contexto de la abolición (Minas Gerais, 1886-1888)

\section{JULIANO CUSTODIO SOBRINHO ${ }^{I^{*}}$}

\footnotetext{
' Universidade Nove de Julho, (UNINOVE) São Paulo - SP, Brasil.

* Professor do Departamento de História da Universidade Nove de Julho, (UNINOVE). Doutor em História Social pela Universidade de São Paulo, São Paulo - SP, Brasil. (jcsobrinho@yahoo.com.br), ORCID iD: https://orcid.org/0000-0003-3337-3877
}

Artigo recebido em 15 de novembro de 2018 e aceito para publicação em 8 de março de 2019. 


\section{RESUMO}

As mais recentes pesquisas sobre a abolição vêm apontando um processo multifacetado e complexo, que não pode ser entendido apenas pelo simbólico Treze de Maio de 1888. Tais estudos consideram a participação de diferentes agentes que, à sua maneira, produziram distintas e inúmeras ações de ativismo contra o cativeiro. Partindo de uma problematização sobre o discurso religioso e os ideais abolicionistas, este artigo analisa a presença de católicos e presbiterianos em Minas Gerais, entre 1886 a 1888, período em que as movimentações sociais ficam mais agitadas e decisivas. Por meio da documentação de polícia e dos jornais, foi possível analisar a participação do clero católico e de presbiterianos numa trama de disputas políticas, interesses pessoais e ideias abolicionistas. Somada a tantas outras manifestações populares, produzidas por escravizados e libertos na região, essa atuação minou, pouco a pouco, os pilares da escravidão.

PalaVRas-CHAVE: Abolição; Abolicionismo; Catolicismo; Presbiterianismo; Minas Gerais.

\section{ABSTRACT}

The latest research on abolition has indicated a multifaceted and complex process, which cannot be understood only by the symbolic date of May $13^{\text {th }}$, 1888 . These studies consider the participation of different social agents who, in their own way, produced distinct and numerous actions of activism against captivity. This article analyzes the presence of Catholics and Presbyterians in Minas Gerais from 1886 to 1888, a period in which social movements are more agitated and decisive, based on a problematization of religious discourse and abolitionist ideals. Through police documentation and newspapers, it was possible to analyze the participation of the Catholic clergy and of Presbyterians in a network of political disputes, personal interests and abolitionist ideas. In addition to so many other popular manifestations produced by slaves and freedmen in the region, these activities gradually undermined the pillars of slavery.

KeYWORDS: Abolition; Abolitionism; Catholicism; Presbyterianism; Minas Gerais.

\section{RESUMEN}

Las más recientes investigaciones sobre la abolición ven señalando un proceso multifacético y complejo que no puede ser entendido únicamente por la simbólica fecha del Trece de Mayo de 1988. Tales estudios consideran la participación de diferentes agentes que, a su manera, produjeron diversas e inúmeras acciones de activismo contra el cautiverio. Partiendo de una problematización sobre el discurso religioso y los ideales abolicionistas, este artículo analiza la presencia de católicos y presbiterianos en Minas Gerais entre 1886 y 1888, período en el cual los movimientos sociales se muestran más agitados. A través de documentación de la policía y de periódicos, fue posible analizar la participación del clero católico y de los presbiterianos en una trama de disputas políticas, intereses personales e ideales abolicionistas que, sumada a tantas otras manifestaciones populares provenientes de esclavizados y libertos en la región, minaron, poco a poco, los pilares de la esclavitud.

Palabras ClaVes: Abolición; Abolicionismo; Catolicismo; Presbiterianismo; Minas Gerais. 


\section{AS LUTAS ABOLICIONISTAS E O CLERO CATÓLICO}

s vésperas da abolição, a tensão social ganhou as ruas das pequenas cidades do sul de
Minas Gerais. O conflito entre escravistas e abolicionistas, que produziu ameaças e perseguições a escravizados e agentes da lei (advogados, delegados, policiais e juízes), envolveu toda a cidade de Três Pontas. Tal tensão imprimiu sua marca, que também contou com uma militância religiosa que, não contente apenas com o púlpito da igreja, produziu lutas com significados abolicionistas. A participação do padre Joaquim Soares Calixto, líder e porta-voz do Club Abolicionista Três-Pontano, possibilita refletir sobre como o discurso e a prática religiosa influenciaram o rumo final da escravidão no Brasil.

Em 12 de agosto de 1887, a cidade foi tomada por centenas de cavaleiros para agredir e matar 4 advogados, dentre os quais os presidentes do Club Republicano e do Club Abolicionista Três-Pontano. Armados e com galões de querosene, o bando partiu para o ataque querendo incendiar casas e expulsar os abolicionistas da cidade. Atônita, a população se viu desprotegida com a guerra anunciada. A escassa força policial, juntamente com o juiz, procurou conter os fazendeiros. Os advogados eram vistos como "inimigos da ordem", pois teriam propagado aos quatro venntos que "não defendiam causas contra a liberdade do homem escravo, por serem abolicionistas". ${ }^{1}$

0 presente texto tem como intuito contribuir para as recentes discussões sobre o processo de abolição, em que se levantam as vivências e experiências de líderes católicos e presbiterianos no contexto final do escravismo, mais especificamente nos derradeiros anos de 1886 a 1888, em que o discurso religioso atravessa, muitas vezes, as ações daqueles sujeitos. 0 artigo não se propõe discutir uma profunda relação entre profissão de fé e a abolição, mas defender que essa associação não esteve ausente nem distante do contexto brasileiro. 0 foco está na atuação religiosa, mas o texto também clarifica a participação popular, com o povo aqui entendido como os escravizados, libertos e todo o populacho, que, nas esferas menos visíveis da sociedade, enfrentaram os últimos pilares da resistência escravista.

As narrativas ora apresentadas fazem parte de uma coletânea de documentos de polícia e de jornais produzida para o sul de Minas Gerais, um dos últimos redutos escravistas naquele momento, região com pouca adesão à imigração e à mão de obra nacional, saudosa dos tempos da ordem e da pujante presença de escravizados no trabalho das fazendas. ${ }^{2}$ Apontada como a província com o maior contingente cativo do Império, às vésperas da abolição, com economia baseada fortemente na agropecuária (Slenes, 1985: 149), a ideia de um enredo abolicionista "pacato" e inspirado na "mineiridade" (Oiliam, 1962) não coadunava com as 
ebulições sociais que aconteceram. Assim, as trajetórias de escravizados, que se somam às dos grupos e indivíduos abolicionistas, provocaram pânico nos resilientes escravistas, que tiveram que lidar com as fugas, revoltas, agitações e projetos de liberdade que inspiravam cotidianamente aqueles que ainda estavam cativos nas lavouras da região.

Mesmo em área escravista relutante em acabar com o trabalho servil, as pequenas cidades do sul mineiro procuraram, ao seu modo, reelaborar as propostas abolicionistas que chegavam no Brasil. Nas principais cidades brasileiras, o movimento abolicionista ganhou força a partir das transformações sociais enfrentadas no final do Oitocentos, como o crescimento urbano, a emergência dos novos setores médios e das instituiç̧ões nascentes, como bancos, comércio, serviços e negócios, e o florescimento da produção econômica após o fim do tráfico (Alonso, 2015: 91-92). Nesse sentido, o poder social que se deslocava dos campos para as cidades, solo fértil para as ideias abolicionistas, também tomava os ideais dos citadinos do sul de Minas, como os abolicionistas do clube de Três Pontas.

Veja-se o efeito que se produziu quando o clube decidiu enfrentar os fazendeiros sul-mineiros. Ao não aceitarem causas que fossem contra a liberdade dos escravizados, os advogados do clube levaram até eles uma gama de pessoas que procuravam justificar legalmente 0 direito à alforria. Muitos escravizados enxergaram nessa aproximação uma estratégia mais eficaz de conquista, como Felicidade, cujo caso se tornou o estopim do supracitado conflito entre fazendeiros e abolicionistas em Três Pontas.

Alegando sofrer maus-tratos diários e ter sido "ameaçada de morte" pelo senhor, Felicidade procurou Custódio de Brito para "tratar dos seus direitos". ${ }^{3}$ Tendo cuidado anteriormente do caso de Adão, marido de Felicidade, Brito tratou de requerer a sua liberdade e garantir proteção ao seu filho. 0 juiz acatou a solicitação, e Felicidade se tornou liberta em poucos dias. Contudo, como ela havia sido comprada em sociedade com outros condôminos, e estes alegaram não ser justo que a punição ao principal proprietário recaísse sobre eles. Solicitaram, assim, que a liberta trabalhasse por mais sete anos como forma de indenização, pedido que foi deferido. ${ }^{4}$

A busca por Felicidade parecia o limite das investidas de escravizados e abolicionistas para aqueles senhores. Não era a fuga de Felicidade e Adão em si que preocupava os fazendeiros, mas os efeitos dessa conquista diante de toda a escravaria. As denúncias de que uma insurreição escrava estava sendo planejada ganharam as páginas dos jornais e o imaginário senhorial. E era de se pressupor que os escravizados souberam ler quando os ventos sopravam a seu favor e trataram de forjar a liberdade. 
Na ocasião de 12 de agosto de 1887, os fazendeiros afirmaram que os advogados perseguidos incitavam fugas, amparavam escravizados e os apoiavam em um plano de insurreição, que havia sido descoberto. Se eram reais tais denúncias, não foi possível saber. Mas fato é que os advogados já haviam causado bastante transtorno para aqueles homens, que, além de enfrentar a escassez de mão de obra, tiveram que se preocupar com a fuga de escravizados em busca dos benfeitores que anunciavam aos quatro ventos que defendiam a liberdade de quem quisesse ser livre.

Parte de todos os escritos sobre o Club Abolicionista foi produzido por padre Calixto, que exerceu presença constante na Gazeta Sul-Mineira, defendendo o grupo contra os ataques dos fazendeiros. Além de ocupar o ministério da Igreja, foi também o fundador do Partido Republicano, chegando a assumir cargos políticos na pós-emancipação, como o deputado de Minas Gerais em 1896 (Miranda,1980: 36). Em artigo para o jornal, padre Calixto afirmou que a causa era justa e, e que os advogados eram apoiados pela população. Sacrificá-los era banhar de sangue as ruas da cidade, assim como faziam nas fazendas com os escravizados. $\mathrm{Na}$ tentativa de elevar os espíritos da caridade e do heroísmo daqueles abolicionistas, o padre criava analogias que mexiam com o imaginário social. Segundo ele, Custódio de Brito, o líder entre os jovens libertários, era um novo "Tiradentes" em solo mineiro, respeitado e merecedor do título de "mártir da redenção". 5

Outro redator frequente nas páginas da Gazeta Sul-Mineira foi Pelicano - pseudônimo que deixava o autor muito à vontade para expor críticas, sem poupar xingamentos aos fazendeiros. Para ele, os integrantes do clube haviam sido vítimas das circunstâncias em que se encontrava a escravidão no País. Pelicano se declarava branco e livre, cidadão contrário à escravidão e preocupado com as agruras do cativeiro. Carregar nas tintas e apontar para uma instituição que padecia, sem deixar de ser cruel, era uma forma de sensibilizar seus leitores a acreditar em suas narrativas. Contudo, ao mesmo tempo em que se vitimizava, o porta-voz do clube endurecia nas palavras ao deixar claro para os senhores que a luta na região tinha um propósito e um objetivo a ser alcançado.

Mas quem seria o ousado Pelicano? 0 próprio padre Calixto ou outro militante? Apesar de não terem sido encontradas evidências sobre a identidade desse personagem, é irresistível não creditá-la ao religioso. Os fazendeiros criticados diariamente nos periódicos também insinuavam que sim. Em resposta aos abolicionistas, os fazendeiros procuraram as páginas do Monitor Sul-Mineiro para se defender dos ataques sofridos pelo grupo. Sob o pseudônimo de "Enxame de fazendeiros", o redator inicia o texto afirmando que "Pelicano é uma máscara, e nós não nos divertimos com mascarados" ${ }^{6}$ Logo em seguida, as investidas são contra o padre 
Calixto, como se o texto falasse da mesma pessoa, "o heroe que devíamos enfrentar, porque nos sucessos de Três Pontas, figurou como o principal protagonista" .

Tanto Pelicano quanto padre Calixto se utilizavam de passagens bíblicas e citações filosóficas para criticar os fazendeiros. Segundo o artigo publicado no Monitor, o papel do sacerdócio não era incitar a população contra cidadãos de bem, e o propósito do padre extrapolava suas funções de religioso. Pelo fato de ele não se manter nos limites do púlpito da igreja, o artigo rejeitava a atuação do líder, pois "um ministro do Senhor tem por alta e nobre missão procurar a paz na terra entre os homens e conquistar [almas] para o céo, e o reverendíssimo padre Joaquim Soares Calixto transviou-se dessa missão, inverteu o seu papel, e transformou-se em advogado do diabo". ${ }^{8}$

Para além dos escritos na Gazeta Sul-Mineira, nada mais encontramos de autoria de padre Calixto ou Pelicano. A reboque dos discursos de promoção do seu partido, o padre defendia as ideias da abolição, procurando justificar que o desespero dos senhores se devia às próprias anormalidades perante as leis - os castigos excessivos aos escravizados, o não cumprimento das matrículas e a reescravização de sexagenários. 0 castigo dos céus que aqueles senhores recebiam era o abandono dos trabalhadores das fazendas.

Como ministro da Igreja, a ousadia de padre Calixto não era a única a ser divulgada nos jornais e no espaço público. Nos anos finais da escravidão, membros do clero assumiram um discurso mais incisivo a favor da abolição, mesmo diante da discrição dos cânones da Igreja. As irmandades religiosas negras, desde o período colonial, já demonstravam formas de resistir à escravidão, procurando acumular pecúlios para a compra de alforrias (Soares, 2000). Ao adentrar a segunda metade do Oitocentos, muitas irmandades produziram críticas à continuidade do elemento servil, manifestando um catolicismo mais "popular" frente às formalidades da prática religiosa das elites e do alto clero.

Apesar da resistência do setor católico mais conservador e defensor das interferências da Igreja no Estado, os projetos modernizadores que ventilavam com mais frequência, principalmente a partir do último quartel do século XIX, impuseram um desafio para os seus membros frente às ideias do progresso, das ciências e da liberdade, que pululavam pelo País.

Os novos tempos condenavam algumas posturas católicas, colocando em xeque a sua própria participação, considerada acanhada nas discussões sobre os rumos da escravidão. Dessa forma, fiéis e sacerdotes assumiram posicionamentos distintos, que, por vezes, ficavam na contramão dos ditames da Igreja. Alguns fiéis se descolaram dos figurinos clássicos que vestiam a prática religiosa, apostando nas novas ideias de nação que penetravam no cotidiano, sem que isso significasse desvinculação com as suas crenças (Abreu, 1999: 316-326). 
Nesse sentido, ao engendrar suas lutas abolicionistas nas páginas dos jornais e nas disputas políticas, padre Calixto era influenciado pelas transformações sociais que o País viveu no limiar da abolição. Como um representante do clero e militante do Partido Republicano, ele enxergava nos novos projetos civilizatórios e políticos os motivos que deveriam definir seu prelado.

Atuações de sacerdotes a favor dos projetos abolicionistas em Minas Gerais não eram raras, mesmo diante do apego à escravidão até as vésperas do Treze de Maio. Os confrontos entre bispos e padres, favoráveis e contrários ao cativeiro, se davam por meio dos púlpitos, das missões religiosas, e em correspondências trocadas entre as autoridades. Ao estudar as sociedades emancipadoras das comarcas de Diamantina e Ouro Preto, Luiz Gustavo Cota (Cota: 2013: 178-179) também pôde acompanhar as iniciativas de tais grupos a partir das arrecadações para a compra de alforrias e na promoção de discursos em prol das ideias abolicionistas, mesmo que de forma bastante tímida.

Para padre Calixto, cabia aos cristãos proteger os "justos" e garantir a pregação dos "mártires". Era a crença em uma prática gloriosa, uma marca da Igreja Católica, que propagava as histórias heroicas de santos e bem-aventurados que deram suas vidas em defesa do próximo e do sagrado. Essa ardorosa defesa do religioso aos abolicionistas trazia para si não só a imagem de porta-voz, mas simbolizava um discurso paternal e protetor em benefício de seus colegas. A ponto de escrever na Gazeta Sul-Mineira que, se ansiavam assassinar os abolicionistas, que antes "descarregassem seus golpes de morte" sobre ele próprio. Oferecer a sua vida em prol dos seus protegidos era doar o sangue e o corpo em favor dos seus "filhos", assim como fez o lendário "pelicano eucarístico", símbolo católico que representa o deus que se ofereceu em sacrifício para salvar a humanidade.

Dessa maneira, padre Calixto doava sua vida à causa, forjando para si a imagem de salvador. A ideia de conceder aos "pobres" escravizados a liberdade também era uma ação cristã, uma benfeitoria, levando adiante o ensinamento basilar de "amar o próximo como a ti mesmo". Assim, o baixo clero, que estava mais próximo dos populares e escravizados, reafirmava o papel de orientar a vida desses sujeitos num mundo em transformação. Apesar de a perspectiva paternalista-humanitária fazer parte do imaginário e das ações de alguns abolicionistas e republicanos, que subestimavam a capacidade de resistência e articulação dos escravizados (Daibert, 2004: 124-125), parece que o padre sabia que a insubordinação negra que se armava naqueles tempos dava sinais de que a abolição poderia surgir como um risco à ordem social.

Se, para os católicos, "Deus escreve certo por linhas tortas", a liturgia produzida por sujeitos como padre Calixto parece exemplar desse ditado, e desvela um oásis de possibilidades para o entendimento sobre o abolicionismo e sua relação com o pensamento cristão. 
Mas que fim teria levado o padre Calixto após os eventos de agosto de 1887? Segundo os relatos dos memorialistas, o sacerdote intensificou sua campanha republicana e, com a derrubada da Monarquia, tornou-se deputado por Minas Gerais ao longo dos primeiros anos da República. Nas obras sobre a história de Três Pontas, padre Calixto parece não ter entrado no rol dos ilustres da cidade, sendo mencionado de forma bastante rápida, quando da criação do Partido Republicano (Miranda, 1980: 36).

Contudo, nos escritos memorialísticos sobre o conflito em Três Pontas, outra figura religiosa pareceu ganhar destaque, sendo considerada a redentora, aquela capaz de libertar Felicidade do cativeiro. Segundo Amélio Miranda (ibidem: 44), a paz só voltou a reinar na cidade por conta da intervenção de padre Francisco de Paula Victor, conhecido popularmente como padre Victor, negro e figura lendária no Sul de Minas, beatificado pela Igreja Católica em 2015. ${ }^{9}$

Nascido em Campanha em 1827 e filho de escravizada com pai desconhecido, padre Victor é figura mitológica na região. De acordo com seu processo de beatificação, ele foi escravo de Marianna Bárbara Ferreira e, mais tarde, foi apadrinhado pelo bispo de Mariana, dom Antônio Ferreira Viçoso, que o conduziu para os estudos no seminário daquela cidade. Como pároco em Três Pontas, a trajetória de padre Victor foi marcada pela luta e conquista por inserção social, em um contexto em que a cor era um importante elemento de identificação e hierarquia, e em um contexto de forte crescimento da racialização das relações sociais. Sua fama de milagroso e benfeitor se espalhou rapidamente pela região, e sua pastoral o envolvia no trato com os doentes e com a escolarização de crianças pobres. Atuante e disposto a ser aceito pela população local, o padre negro fundou escola e realizava exorcismos sempre que "maus espíritos" se apossavam de seu rebanho (ibidem: 144).

Pela breve biografia de padre Victor supramencionada, fica evidente que o sacerdote foi contemporâneo dos personagens de que tratamos até aqui. Segundo o memorialista Amélio de Miranda, teria sido ele que, "empunhando o crucifixo na entrada da cidade", em 1887, exigiu que os fazendeiros deixassem a cidade (ibidem: 146). 0 "feito heróico" atribuído ao padre Victor livrou Felicidade, Adão e os abolicionistas das garras dos fazendeiros, e ele, impelido pelo "nobre sentimento de gratidão", bradou a todos eles que, se estivessem dispostos a cometer qualquer violência, teriam que passar "por cima do corpo do Vigário" (idem). A figura salvacionista, como a do "pelicano eucarístico" que dava a vida pelos fieis, foi novamente apropriada, dessa vez para eleger padre Victor como o herói do desfecho daquele cenário, às vésperas da abolição.

Além destes relatos, nada encontramos na documentação pesquisada a respeito de qualquer participação de padre Victor nos episódios de Três Pontas. Podemos arriscar que a entra- 
da do sacerdote para a memória oficial da cidade, no que tange aos conflitos pela abolição que se deram naqueles tempos, parece incidir com as intencionalidades de se construir uma imagem de santidade para o padre negro, desde sua morte até os dias atuais.

Alçado ao posto de "redentor" dos escravizados, e por ter dedicado sua vida aos mais pobres e desvalidos, padre Victor tem, hoje, sua história como uma das atrações do circuito turístico religioso da região. Atualmente, o sacerdote é postulante a se tornar o primeiro santo negro do Brasil em processo de santificação aberto no Vaticano. Para a tradição popular e local, padre Victor já é santo, transformado pelo povo em uma entidade arquetípica, ao mesmo tempo divina e guerreira, capaz de ter dado a vida pelos seus seguidores e pela defesa da justiça entre os homens.

\section{OS PRESBITERIANOS NO LIMIAR DA ABOLIÇÃO}

E m fins do século XIX, missões presbiterianas percorreram o sul de Minas Gerais convertendo pessoas e auxiliando-as na fundação das primeiras comunidades. Tendo emigrado dos Estados Unidos para o Brasil a partir da década de 1860, os presbiterianos traziam consigo mais do que o projeto missionário: a Guerra Civil e a abolição da escravidão nos Estados Uni,dos conferiram à questão escravista lugar de destaque em seus discursos e reflexões e impactou os processos emancipatórios no restante do continente (Miranda, 2017: 26-28). Para parte dos imigrantes, a busca pela "terra prometida" era um pretexto, uma estratégia de negar a sociedade pós-escravista organizada em seu país de origem (Brito, 2014: 160). Para eles, a vinda para o Brasil simbolizava a busca pela continuidade e pela possibilidade de retomar as vivências senhoriais.

Os missionários presbiterianos americanos sulistas e nortistas, algumas vezes, representavam posições ideológicas e políticas diferentes em relação às questões escravistas e abolicionistas, tendo, a despeito disso, unido forças na busca de terreno religioso, em uma seara desconhecida e adversa. Se sobrepunha às divergências um "destino comum" revelado, sendo preciso "cumprir os desígnios de Deus, através do estabelecimento de 'um novo processo civilizatório'" (Oliveira, 1995: 106).

Alinhados com novas diretrizes do liberalismo, os missionários passaram a bradar pela ampliação da liberdade de culto e pelas bandeiras do cientificismo, da república e da abolição da escravidão no Brasil (Abreu, 1999: 316-317). Além disso, há registros de convertidos brasileiros que, logo após abraçarem o presbiterianismo, se envolveram com os dramas da escravidão em seus momentos derradeiros. 
Ao longo da pesquisa realizada no Acervo de Polícia do Arquivo Público Mineiro, tivemos contato com diversas correspondências sobre um núcleo presbiteriano em Cabo Verde (MG) acusado de participar das "desordens" abolicionistas que tomavam conta da região em 1887. Naquele ano, o delegado Antonio de Pádua Dias se envolveu em uma imbricada história, ao defender um sexagenário que lhe pediu socorro contra seu antigo senhor, que queria reescravizá-lo. ${ }^{10}$ Tal episódio constituiu um dos motivos das inúmeras acusações que recaíram sobre o delegado, custando-lhe o cargo público.

Antonio de Pádua Dias e seu irmão, Francisco de Assis Dias, foram convertidos ao presbiterianismo em 1879 pelo missionário americano John Boyle e pelo missionário convertido Miguel Torres. ${ }^{11}$ Logo, ajudaram a formar o primeiro núcleo presbiteriano na cidade. Antonio de Pádua era sitiante, mas já havia sido tropeiro, comerciante, policial e rábula, antes de assumir a delegacia. Os primeiros cultos aconteceram na casa da família Dias, e quando o missionário John Boyle e o colportor ${ }^{12}$ Felipe Wengenton chegaram a Cabo Verde, Antonio de Pádua Dias passou a realizar os cultos dentro dos salões da loja maçônica, da qual era membro. ${ }^{13}$

A assistência mútua entre protestantes e maçons no período representava os anseios daqueles indivíduos diante das ideias liberais, da valorização da liberdade de culto, da educação e das razões do progresso e da civilização no Brasil. Além disso, a Igreja Presbiteriana e a Maçonaria somavam forças frente à perseguição católica (Mansur, 1999). Ao realizar os primeiros cultos da Igreja Presbiteriana na loja maçônica, Antonio de Pádua Dias se colocou cada vez mais em rota de colisão com os católicos da cidade. Não à toa, os conflitos que se deram em Cabo Verde a partir de sua demissão desencadearam uma série de questões que estavam em disputa no campo social, que perpassavam razões pessoais, políticas e religiosas, e que seriam potencializadas pelas acusações apresentadas por seus adversários de que ele seria favorável às causas abolicionistas.

A cruzada católica contra as atuações protestantes em Cabo Verde teve na figura do suplente do juiz municipal Luiz Antonio Navarro uma ardorosa militância, na tentativa de derrubar Antonio de Pádua Dias do comando da delegacia. Em outra correspondência encaminhada diretamente à Presidência da Província, o suplente acusou o grupo de Antonio de Pádua Dias de "gente ruim, mais própria para salteadores, que anda aos bandos, cantando pelas estradas, cathequisando os pobres ignorantes". ${ }^{14}$ Desamparados, os cidadãos estavam expostos aos perigos provocados pela desobediência daquela gente presbiteriana, que tinha na figura pública do delegado o "presbítero da seita". 15

Os conflitos religiosos no sul mineiro estamparam as páginas da Gazeta de Notícias, no Rio de Janeiro. Uma carta enviada ao periódico informava os abusos de Antonio de Pádua Dias 
por abandono da delegacia em função de seus compromissos com a fé protestante, chegando a deixar a cadeia "deserta" de policiamento e a cidade vulnerável aos desmandos daquele momento de crise da escravidão. Como solução ao descalabro na cidadezinha mineira, a sugestiva carta solicitava que o ministro da Justiça substituísse imediatamente o delegado por outro cidadão capaz de zelar pela segurança e pela manutenção da ordem. ${ }^{16}$

0 primeiro grupo presbiteriano de Cabo Verde esteva inserido em um bairro da cidade que hoje recebe o nome de São Bartolomeu. De acordo com os memorialistas, aquela era uma área afastada do centro urbano, que fazia parte do complexo cafeicultor da região (Ferreira, 2010: 115). Ao denunciar as "badernas" produzidas por aquele grupo de "pobres ignorantes", Luiz Antonio Navarro promovia uma perspectiva de inferiorizar os protestantes frente aos católicos e suas famílias distintas e bem-nascidas. ${ }^{17}$ Acontece que a família Dias se tornou uma poderosa força para a evangelização na região, e conduziu uma massa de gente simples, possivelmente, também formada por libertos e negros livres, que acompanhava o ministério liderado por Antonio de Pádua e Francisco de Assis: "os pobres, dizia Pádua Dias, são nossos irmãos; guardemos a coragem para enfrentar os ricos" (idem). Assim, o discurso de preocupação de Luiz Antonio Navarro, ao denunciar os presbiterianos, ganha mais sentido, posto que, antes vigiados e repreendidos pela força policial, estavam naquele momento se servindo dela, representada pela figura do delegado.

Ao ser destituído do cargo, Antonio de Pádua Dias foi substituído por seu irmão, o suplente Francisco de Assis Dias, que foi incansável defensor do delegado contra as acusações de Luiz Antonio Navarro. Segundo ele, era evidente que havia uma perseguição política e pessoal arquitetada pelos descrentes da fidelidade de Antonio de Pádua Dias à política imperial e ao cumprimento das leis. Além disso, tanto ele quanto o irmão eram perseguidos por professarem o presbiterianismo. Em discurso nas inúmeras correspondências que enviou para a chefia de polícia e para a Presidência da Província, Francisco de Assis Pádua procurava construir para si e para o irmão uma narrativa que os vitimizasse frente às injustiças de senhores e católicos da cidade. Para isso, utilizava metáforas bíblicas para expor sua versão dos fatos e recuperar o cargo de Antônio de Pádua. Ele afirmava ser "servidor fiel do governo e de deos", e dizia não temer os "filisteus", porque a justiça de "deos e dos homens triunpham" ${ }^{18}$

No apelo religioso percebido nas palavras de Francisco de Assis, era possível verificar associações bíblicas com o drama vivido pelo irmão. A imagem de Antônio de Pádua era narrada como a de um verdadeiro "apóstolo", perseguido e injustiçado por seus opositores políticos, que se comportavam como grandes caluniadores contra um "servo de Deus em nome da Justiça". ${ }^{19}$ Para Francisco de Assis, ao denunciarem as irregularidades do mandonismo local, não 
fizeram nada além do que as leis os obrigavam, sempre com a justiça de Deus e a dos homens, mesmo sabendo que as consequências poderiam se voltar contra eles.

Apesar do posicionamento do juiz municipal de Caldas, José Ignácio de Barros Cobra Júnior, de que Antonio de Pádua apenas cumprira a lei ao não aceitar a manutenção do cativeiro de um sexagenário, além da ausência de provas quanto ao aliciamento de escravizados fugidos, outros elementos foram acrescentados à denúncia. ${ }^{20}$ Sua atuação como rábula anos antes de assumir a delegacia promoveu a liberdade de alguns escravizados, por meio das ações de liberdade, e este fato endossava os argumentos de Luiz Antônio Navarro.

Assim, as denúncias feitas contra o delegado representam uma grande reunião de interesses locais. A crescente insubordinação negra, somada às atuações de advogados e autoridades frente aos interesses senhoriais, tensionavam as relações entre os homens da lei e os escravistas. Antonio de Pádua Dias nada mais fez do que colocar em prática, tanto como rábula quanto como delegado, aquilo que interpretava das leis emancipacionistas em prol de seus próprios interesses e das causas que defendia.

Fato é que, em nossa pesquisa, não encontramos evidências de que Antônio de Pádua tenha se envolvido com um abolicionismo formal. Sequer encontramos escritos do próprio delegado discorrendo em sua defesa. Contudo, é lógico pensar que tanto sua atuação na libertação de escravizados, por meio de ações de liberdade, quanto o cumprimento de suas funções como autoridade deram a ele o figurino apropriado para que fosse visto como um radical, desertor dos interesses senhoriais. Vale pontuarmos também que, mesmo ao agir de acordo com as leis, os irmãos Dias não negaram em momento algum o poder coercitivo da polícia no combate às repressões sobre as revoltas escravas e na preservação do direito à propriedade privada (Santos, 1980: 49). Cada qual o via de acordo com o prisma que lhe era mais conveniente. As outras ocorrências da delegacia de Cabo Verde, que revelavam o dia a dia dos afazeres da polícia no combate aos escravizados fugidos ou contra aqueles que se rebelavam, nos deixam cientes disso. ${ }^{21}$

0 que talvez colocasse os irmãos Dias em rota de colisão com os fazendeiros mais resistentes ao fim do escravismo no cenário sul-mineiro estava ligado ao forte apego à mão de obra escrava por parte de alguns proprietários, que enxergavam somente na escravidão a sobrevivência da lavoura e de seus negócios. Em uma região com ares rurais bem definidos e uma produção cafeeira considerável, Cabo Verde poderia ser um palco perigoso para qualquer autoridade que buscasse agir conforme os ditames das leis emancipadoras, mesmo que não alardeasse nada a favor da extinção do cativeiro.

Vale lembrar que as ameaças contra a integridade de autoridades eram uma constante naqueles anos derradeiros da escravidão (Machado, 2011: 26-28). Sem outros agentes que 
tornassem públicas suas ideias abolicionistas e que engrossassem as fileiras da causa na cidade - mesmo que elas fossem regidas por práticas que somente estabelecessem as estratégias das alforrias condicionais e do controle do trabalho do liberto -, a integridade de agentes como os irmãos Dias parecia estar mesmo em sério perigo.

Ao ser acusado de "advogado dos escravos", tratou logo de se apoiar nos serviços do colega advogado Alberto John Monteiro de Barros, que se prontificou a enviar à Secretaria de Polícia uma série de ofícios de juízes da região que comprovavam serem falsas as acusações. Além disso, o advogado requereu do juiz de órfãos certidões das decisões de ação de liberdade em que Antonio de Pádua estava envolvido. E, de acordo com o ofício, o delegado havia realmente conseguido deferir algumas solicitações, como as dos escravizados Domingos, Felicidade e do casal Adão e Narciza. ${ }^{22}$

Infelizmente, as ações de liberdade que foram abertas pelo nosso personagem não foram encontradas nos arquivos consultados. Mas os ofícios encaminhados à Secretaria de Polícia nos deram conta de que, desde a década de 1870, Antonio de Pádua tinha executado a abertura de pelo menos 12 pedidos de liberdade, entre eles as solicitações dos africanos Domingos, Pedro e Joanna e seus filhos, que vieram para o Brasil cerca de 20 anos após a Lei de $1831 .^{23}$ Sua carreira como advogado também fora impulsionada pelos anúncios que ele mesmo divulgava nos jornais, como encontrado na edição de 1883 do Liberal Mineiro, de Ouro Preto, quando publicou sobre seus serviços nas causas dos escravizados. ${ }^{24}$

Na correspondência para a Secretaria de Polícia, em fins de 1887, parece-nos que Antonio de Pádua Dias foi vitorioso em sua luta pela volta ao cargo de delegado. De acordo com o documento, o governo provincial atestava que, em consulta ao ministro da Justiça, não havia nada que desaprovasse a figura do acusado, tendo suas ações sido geradas dentro da lei. Da mesma forma, sua profissão de fé protestante não impedia que fosse delegado, visto que 0 cargo não era restrito aos indivíduos que pertenciam à religião oficial do Estado. ${ }^{25}$

Ciente de que sobre si pesavam duas acusações e que elas poderiam comprometer o seu cargo - a filiação protestante e a fama de "advogado dos escravos" -, preferiu ele assumir a primeira e negar a segunda, por ser um denominativo comprometedor diante dos projetos que queria conquistar. 0 fato é que a trajetória dos irmãos Dias, mais especificamente o drama social em que esteve envolvido Antonio de Pádua Dias, nos revela a dinâmica dos enredos ligados às agendas da abolição, em meio a uma imensidão de histórias de indivíduos que reagiram de maneiras muito diversas e complexas.

Contudo, na história eternizada nos relatos memorialísticos, nos parece convincente que os Dias (e seus descendentes) trataram de alcançar o posto de anfitriões da comunidade pres- 
biteriana do sul mineiro, bem como de destacar seus feitos no campo jurídico da cidade. Já nas vésperas da abolição, Antonio de Pádua aderiu às ideias republicanas e se tornou promotor público em Cabo Verde. Francisco de Assis pleiteou o cargo de vereador no mesmo período. Nenhuma menção ao denominativo "advogado dos escravos" parece ter sobrevivido ao tempo, pelo menos não nos escritos dos memorialistas (Carvalho, s.d.: 240-249).

\section{A INTELECTUALIDADE PROTESTANTE NA LUTA CONTRA A ESCRAVIDÃO}

$E^{n}$ m 1886, a Igreja Presbiteriana, diante das inúmeras movimentações sociais que se apresentavam nas ruas e no Parlamento, resolveu condenar a escravidão em seu $22^{\circ}$ Presbitério, realizado no Rio de Janeiro. Para isso, os missionários americanos e os presbíteros brasileiros tomaram como inspiração a Declaração da Assembleia Geral da Igreja Presbiteriana dos Estados Unidos, de 1818. Em consonância com as transformações que conclamavam pelo progresso e pelos ideais civilizatórios no País, os religiosos discutiram sobre os dilemas da instituição escravista e sua Igreja, " desejando ardentemente que este país se liberte do grande mal da escravidão, vê com alegria a propaganda abolicionista se firmando no terreno seguro da consciência cristã" (Lessa, 2010: 165-168).

Por iniciativa de Eduardo Carlos Pereira - pastor e intelectual presbiteriano que havia movimentado aquela década final da escravidão com sua militância abolicionista -, o concílio congratulou-se com a campanha pela abolição brasileira, e coube a ele proferir a Abertura Anual do Presbitério (ibidem: 265). Nascido em 1855 em Caldas, Minas Gerais, em uma fazenda escravista voltada à agropecuária de subsistência e de abastecimento, Eduardo Carlos construiu uma trajetória de vida dedicada aos estudos e à profissão de fé. Sua iniciação no presbiterianismo é atribuída a George N. Morton, que chegou com a Junta Missionária do Sul em 1869. (Matos, 2004: 171-175).

Mais tarde, Eduardo Carlos se transferiu para São Paulo com a pretensão de estudar na Faculdade de Direito do Largo de São Francisco, objetivo não alcançado. Na capital, sua forma-

ção esteve sob a responsabilidade dos reverendos George Chamberlain e John Beatty Howell, ambos missionários do Norte dos Estados Unidos, o que pode ter dado a ele inspiração para a militância religiosa e abolicionista. Com o crescimento do movimento em São Paulo, Chamberlain acolheu os filhos de republicanos e abolicionistas que estavam sofrendo represálias nos outros colégios da cidade (Matos, 1999: 68).

Na década de 1880, Eduardo Carlos partiu para as missões no interior de São Paulo e de Minas Gerais. Grande parte de sua atuação no abolicionismo foi desenvolvida quando era 
pastor em Campanha no sul mineiro. Por meio do mundo das letras, do ensino e das missões evangélicas, ele se inseriu nas lutas pela abolição, forjando um intenso debate na imprensa e angariando adeptos protestantes e inimigos escravistas.

Naquele contexto, a educação formal protestante destinava-se à formação de uma nova elite brasileira, prezando por um ensino liberal e progressista, reverberado pelos currículos americanos. De acordo com alguns missionários, a evangelização era uma consequência natural da educação formal (Oliveira, 1995: 162-166). Tal qual fosse a experiência protestante, nos colégios ou nas igrejas, esta não poderia ser vivenciada sem que a consciência cristã influenciasse seus fiéis nas leituras que produziam sobre a realidade escravista brasileira.

Diferentemente dos irmãos Dias, Eduardo Carlos imergiu na formação intelectual ao mesmo tempo em que militou pelo abolicionismo por diversos cenários da escravidão, em suas andanças pelo sul de Minas, Rio de Janeiro e São Paulo. Sua chegada em Campanha se deu em 1883, quando assumiu a liderança da Igreja Presbiteriana na região. Além de desenvolver uma agenda abolicionista, nosso personagem se envolveu nas disputas religiosas com os católicos da cidade, representados na figura do padre José Theophilo Moinhos de Vilhena. 0 Monitor Sul-Mineiro abriu espaço para os dois pastores, que se dispuseram a usar as páginas do periódico. Para o padre José Theophilo, o protestantismo era uma "religião falsa, completamente falsa, galho decepado da grande árvore do catholicismo, o protestantismo estrebucha, contorce-se em movimentos automáticos, sem direção, norte, princípio e nem fio" ${ }^{26}$

A resposta imediata de Eduardo Carlos se resumiria no versículo bíblico "ide por todo 0 mundo e pregai o evangelho a toda creatura". ${ }^{27}$ Diante do princípio salvacionista e de busca de uma nova "Canaã", o presbiteriano desenvolvia seu discurso para defender a ideia de que a fé deveria estar livre do atraso e da omissão dos católicos. Nesse caso, ele criticava a Igreja Católica por não assumir um discurso mais efetivo na luta abolicionista. Como missionário, ele estava preparado para todas as intempéries que seus algozes pudessem provocar. Já o padre José Theophilo buscava alertar seus fiéis para que não fossem ludibriados pela sedução da fala protestante, causadora de "anarchias" e "rupturas" e em defesa de um princípio de liberdade que não era cristão. ${ }^{28}$ Certamente, o sacerdote parecia compactuar com os setores católicos que preferiram se omitir do enfrentamento abolicionista até às vésperas do Treze de Maio. As divergências entre os dois ministros cristãos se arrastaram pelos jornais durante o período em que Eduardo Carlos residiu na cidade, encerrando-se com sua transferência para São Paulo, em 1888, para assumir a Igreja da capital.

Se Antonio de Pádua Dias usava os tribunais e a delegacia para se posicionar socialmente em espaços anteriormente dominados por católicos, Eduardo Carlos buscou atuar no ensino 
e na formação pastoral, da mesma forma que se escorou na imprensa para garantir que fosse ouvido. Além do Monitor Sul-Mineiro, ele era correspondente do jornal Imprensa Evangélica, publicado quinzenalmente no Rio de Janeiro,entre 1864 e 1892. Já na pós-emancipação, se envolveu com os estudos da gramática, bem como foi um dos fundadores do jornal 0 Estandarte, periódico oficial da Igreja Presbiteriana Independente. Na vida de nossos dois personagens, a evangelização ganhava destaque, o que não impediu que desenvolvessem inúmeros projetos que, de alguma maneira, esbarravam nos interesses pessoais e coletivos de outras pessoas. Ao seu modo, cada um procurou construir representações, atitudes e práticas que thes asseguravam certa estabilidade e sobrevivência diante dos grandes dramas sociais e políticos do País. E no momento em que as disputas religiosas acrescentavam desafios, parece importante entendermos as potencialidades de as "representações", como afirma Roger Chartier (1990: 23), tecerem as hierarquias do mundo social.

Eduardo Carlos assumiu uma constante luta pela abolição. Em 1886, publicou a obra A religião christã em suas relações com a escravidão, uma coletânea de artigos lançados anteriormente no jornal Imprensa Evangélica, que gerou grande repercussão no meio cristão. Foi fundador da Sociedade Brasileira de Tratados Evangélicos, que durante anos publicou 17 livretos de ideias protestantes, entre eles o supramencionado. Em seu livro, Eduardo Carlos se propôs a não só condenar a escravidão, como também conscientizar seus fiéis das incompatibilidades entre o Cristianismo e o sistema escravista, em especial a profissão de fé presbiteriana, na qual ele acreditava. Era fruto de suas vivências como missionário pelo interior, pregando em igrejas improvisadas e escrevendo em jornais. Eduardo Carlos e os missionários americanos profetizavam o fim da escravidão no Brasil, mostravam a experiência bem-sucedida da abolição dos Estados Unidos, e incitavam os fiéis a libertarem os escravizados. Alguns deles estenderam sua militância em correspondências às lideranças da Igreja e aos políticos dos Estados Unidos, denunciando as mazelas que a escravidão causava no Brasil (Silva, 2010: 56-65).

Os estudos sobre o abolicionismo presbiteriano no Brasil se concentram entre teólogos, memorialistas e intelectuais da própria Igreja e, de acordo com essa literatura, os missionários da Igreja Presbiteriana do Norte sempre foram mais encorajados a produzir críticas sobre a escravidão brasileira. Foram retratados como "abolicionistas convictos", que tinham experiências nas lutas que se deram ao longo do processo da abolição nos Estados Unidos. Já entre os missionários sulistas, parecia haver certo silenciamento sobre essas questões, pelo menos nos escritos deixados por eles. Vale lembrar que, apesar das diferenças ideológicas entre os dois grupos, as necessidades missionárias da evangelização no Brasil obrigaram esses sujeitos a pastorearem conjuntamente, o que também não significa que as divergências fossem total- 
mente vencidas. Logo após o lançamento da obra de Eduardo Carlos, houve uma reação de missionários sulistas, que escreveram um tratado antiabolicionista como crítica às investidas do pastor brasileiro (ibidem: 60).

Segundo Evaristo de Moraes (Moraes, 1986: 240), Eduardo Carlos acertava diretamente outros pastores que, de forma apática ou omissa, se esquivavam da aproximação das parábolas bíblicas com a realidade social. Produzia uma resposta que criticava aqueles que pretendiam conciliar a posse de escravizados com os sentimentos religiosos. Ainda segundo Moraes, os escritos de Eduardo Carlos mobilizavam outros missionários e fiéis que adentraram a campanha abolicionista em São Paulo, militando ao lado de figuras como Antonio Bento. As escolas de cunho protestante passaram a assumir um discurso mais explícito sobre as mazelas sociais provocadas pela escravidão.

Eduardo Carlos afirmava que a escravidão atrasava o progresso brasileiro e constituía um "crime" contra Deus. Em um tom de pregação e de tentativa de convencimento de seus fiéis e leitores, ele lamentava o fato de que muitos cristãos se entregavam ao "sacrilégio" de defender a propriedade escrava, utilizando para isso a "palavra de Deus, de justiça e de amor" (Pereira, 1886: 8). A obra foi dividida em seis capítulos, e versa sobre as impressões do autor sobre o mundo da escravidão, a condenação do cativeiro pela Bíblia, e as diretrizes que os fiéis deveriam seguir para não agir com incoerência diante da ideia da liberdade.

Para ele, a escravidão seria um "roubo", uma síntese do pecado, pois a liberdade seria um "dom primitivo" de Deus e essencial para a vida humana. Seu discurso nos auxilia a entender como as transformações da ideia sobre o pecado fomentaram o pensamento antiescravista, sobretudo o pensamento protestante (Davis, 2001: 329-336). Ao evocar também o "cientificismo" e a razão da intelectualidade brasileira, acreditava ele que as evidências contrárias à continuidade da escravidão estavam postas na sociedade. Eduardo Carlos elevava as lutas abolicionistas do último quartel do Oitocentos lamentando essa frente não ter sido lançada em tempos anteriores (Pereira, 1886: 28-29). Nos ensejos dos últimos suspiros da escravidão e em um momento de efervescência das ideias abolicionistas, ele procurava angariar a simpatia de um maior número de adeptos para as causas da abolição.

Eduardo Carlos falava a linguagem da religião para professar suas ideias sobre a abolição, em que o sagrado ocupava o centro das discussões e conduzia à liberdade. Esse parece um ponto instigante para repensarmos o papel do abolicionismo brasileiro, melhor dizendo, a densa construção desse movimento que produziu discursos e ações bastante diversas.

Como um segmento desse abolicionismo religioso - defendido tanto por missionários americanos quanto por brasileiros - é representativo da presença presbiteriana no Brasil, 
discordamos de Celia Maria de Azevedo (2003), que, ao produzir um estudo comparado entre as dimensões abolicionistas no Brasil e nos Estados Unidos, considerou a dimensão brasileira de "linguagem secular", ou seja, sem envolvimento com princípios religiosos, costurando seus argumentos de forma pragmática e conectada aos interesses da política nacional e do progresso econômico. De acordo com a autora, o abolicionismo americano seria essencialmente religioso, cuja imagem central é Deus, condenando a escravidão pela via da moral e do pecado (ibidem: 43-45). Entretanto, se quisermos compreender um movimento multifacetado, complexo, e que contou com a participação de inúmeros sujeitos, parece que a chave de leitura para o processo abolicionista brasileiro não está somente no formalismo e na atuação política parlamentar.

Em 1903, Eduardo Carlos rompeu com a matriz missionária americana, fundando a Igreja Presbiteriana Independente. Essa cisão não fez com que ele deixasse de admirar as conquistas abolicionistas dos Estados Unidos, valorizando a formação dos movimentos nortistas e 0 progresso gerado na região com o fim da escravidão. Conectado com as campanhas abolicionistas internacionais, dava salvas aos americanos Willian Garrison e John Brown pela luta em seu país, iluminados pelo "fogo sagrado do Evangelho" (Pereira, 1886). As pressões inglesas pelo fim da escravidão no Brasil eram louvadas por meio das figuras de William Wilberfore e Thomas Buxton, que, apoderados pelo "espírito do christianismo" (ibidem), deveriam servir de inspiração para os brasileiros. Para os mais resistentes escravistas, servia a lição tomada pelos próprios sulistas, que, castigados pela resistência que promoveram contra o fim da escravidão, viram o progresso triunfar no Norte do país. ${ }^{29}$

Neste sentido, a cristandade precisava se posicionar e defender a libertação dos escravizados em prol de uma sociedade na Terra que fosse mais justa para uma garantia de salvação divina. Eis:

Se a religião, portanto, que professas, condemna o captiveiro, escolhe entre ella e os escravos que possues. Ou guarda teus escravos, e continua aproveitar do suor do rosto do teu próximo, e, neste caso, imitando o exemplo dos gadarenos, pede a Jesus que se retire de tua casa; ou então, restitue a teus escravos a liberdade roubada e declara por esse acto que não és um mero hypocrita. (ibidem: 36 )

Para Eduardo Carlos, o escravizado era a imagem de Deus e, assim, a sua propriedade pertencia ao criador e era "sagrada". Aos protestantes não cabia o direito de roubar o "direito inviolável" do pastor, que, como senhor de todos - livres e escravizados -, era o único condutor da vida dos seres humanos. A mensagem do presbiteriano era clara, "de um captiveiro amargo e degradante não te libertou o sangue do compassivo Redemptor? E agora ao contemplares teu escravo, não ouves a terrível repulsão de teu Senhor?" (ibidem: 44). 
Ao estudar os missionários batistas no Caribe, Emília Viotti da Costa (1998: 28-33) afirma que o Cristianismo havia se tornado um alento e um modo de iluminar as desigualdades sociais com que se deparavam aqueles fiéis. De qualquer maneira, aquela linguagem bíblica e cristã poderia provocar um sentido de subserviência em um contexto de rebeldia social. Por conta disso, havia uma rejeição ferrenha à presença missionária naquela região por parte de muitos proprietários. Da mesma maneira, Eduardo Carlos sabia os riscos que corria, e que suas ações poderiam provocar incômodos nos mais recalcitrantes escravistas, fossem eles protestantes ou não.

Mesmo assim, às vésperas da abolição e consciente das movimentações que se davam pelo fim do cativeiro, Eduardo Carlos foi convicto em se posicionar frente a uma abolição imediata e capaz de extinguir o "mal" sobre a terra. Por isso, ele postulava a ideia de que 0 púlpito não poderia ser acometido de ressalvas e receios, se a abolição se encontrava à "luz de verdades incontestáveis". Se a escravidão era uma instituição ilícita e ofensiva a Deus, "por que então a reserva, o silêncio medroso ante um crime tão grave?" (Pereira, 1886). Com isso, convocava seus fiéis a criar condições para "dissimular os tempos desta ignorância" (ibidem: 31), devendo tornar o trabalho missionário uma forma de preparação de escravizados que receberiam tal benesse. A reboque de um abolicionismo legalista, dos discursos paternalista-humanitários e dos princípios de tutela sobre o escravizado, considerado incapaz de conduzir sua vida sozinho, Eduardo Carlos reproduzia o tom conservador também presente em outros projetos abolicionistas discutidos até então. Para ele, não bastaria abolir a escravidão, pois seria necessário preparar o "povo" e "elevar a sociedade a comprehensão da justiça e santidade" (idem). Se assim não fosse, "era deitar remendo de panno novo em vestido velho, ou despejar vinho novo em velhos ôdres" (idem).

Apesar dos códigos de conduta e do sentimento de culpa serem bastante alargados nas falas protestantes, sobretudo no que vimos na apresentação da obra de Eduardo Carlos, parte do que ele enxergava do outro era a reprodução de uma visão estereotipada. Assim, se a escravidão era "pecado", caberia aos fiéis levar a "verdade" e preparar os escravizados, moralmente degenerados pelas agruras do cativeiro.

Com escrita enfática e direta, Eduardo Carlos construiu uma narrativa de condenação à escravidão, incitando os fieis a cumprirem os ensinamentos da Igreja em consonância com os mandamentos de Deus. A ideia de um protestantismo que apresentasse uma interpretação bíblica vinculada à realidade e que não aceitava a escravidão de seus pares foi a tônica que movimentou a vida do pastor e intelectual presbiteriano. 


\section{CONSIDERAÇÕES FINAIS}

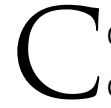

omo apontamos, o sul de Minas contou com um dos maiores contingentes de escravizados no limiar da abolição. Foi uma região de forte permanência da escravidão até os seus últimos minutos, em que os embates pelas ideias escravistas/abolicionistas são essenciais para se entender o denso e multifacetado processo da abolição brasileira. Inseridos no contexto da crise do escravismo, os sujeitos e grupos religiosos que tratamos neste texto produziram discursos e ações que nos convencem de que a religião é também um elemento de compreensão do abolicionismo no Brasil, visto que as ideias escravistas e antiescravistas estavam, sim, atuando com as questões religiosas. 0 envolvimento do baixo clero católico e dos convertidos protestantes demonstra as insatisfações daqueles setores com as políticas do Império, que não atendiam às necessidades dos novos tempos.

De alguma forma, padre Calixto e os presbiterianos percebiam a necessidade de se inserirem na sociedade. A via das ações e discursos abolicionistas - fosse cumprindo as leis, como no caso do delegado Antonio de Pádua, ou incitando a fuga e proteção para cativos, como discursado por Eduardo Carlos -, pode ter sido uma saída encontrada por eles para lutar por seus projetos e pelos significados religiosos que abraçavam.

Assim, padre Calixto seguiu na defesa do abolicionismo orgânico, representado pelo Club Abolicionista Três Pontano, utilizando-se dos jornais e da política para ventilar os propósitos do grupo e defender a liberdade dos escravizados da região. Já os irmãos presbíteros, Antonio de Pádua e Francisco de Assis, buscaram garantir os espaços da delegacia e da Igreja que haviam conquistado, mesmo em tempos difíceis em que estava em jogo uma imbricada disputa de poder local, interesses escravistas/abolicionistas, legalistas e religiosos. A mesma coisa parece ter sido construída por Eduardo Carlos, que, ao ter sua trajetória marcada por um sentido de propagação do presbiterianismo intelectual, não economizou no ativismo ao procurar conscientizar os fiéis ao alinhamento de uma fé mais coerente com os novos tempos.

A partir de agendas que ora se distinguem, ora se assemelham, as trajetórias desses agentes da fé abrem janelas para entendermos melhor os abolicionismos que se desenhavam no Brasil. Apesar de alinhados a grupos de certa elite local ou que buscavam reconhecimento e ascensão, nossos personagens representam novas formas de pensar as bandeiras abolicionistas, que, em contato com sujeitos das esferas populares, contribuíram por sacudir os derradeiros pilares escravistas. Redimensionar as considerações sobre como os religiosos encaravam aqueles projetos poderá trazer novas cores para compreendermos um processo de abolição complexo e multifacetado, que não pode ser resumido apenas a um conjunto de sujeitos ou grupos, tampouco ser entendido pelo viés formalista e conservador que ganhou as páginas historiográficas por longas décadas desde o desfecho do Treze de Maio de 1888. 


\section{NOTAS}

1 Gazeta Sul-Mineira, 25 de setembro de 1887, São Gonçalo do Sapucaí, CECML, fl. 04.

2 A discussão proposta neste texto faz parte da tese de doutorado "Sobre um tempo de incertezas: o processo da abolição e os significados da liberdade em Minas Gerais (1880-1888)", defendida no Programa de Pós-Graduação em História Social da Universidade de São Paulo e publicada recentemente (Custódio Sobrinho, 2018).

3 Gazeta Sul-Mineira, 14 de agosto de 1887, São Gonçalo do Sapucaí, CECML, fl. 02.

4 Monitor Sul-Mineiro, 02 de outubro de 1887, Campanha, CECML, fl. 03.

5 Gazeta Sul-Mineira, 11 de setembro de 1887, São Gonçalo do Sapucaí, CECML, fl. 01.

6 Monitor Sul-Mineiro, 02 dde outubro de 1887, Campanha, CECML, fl. 03.

7 Idem.

8 Idem.

9 A beatificação de padre Victor ocorreu em 14 de novembro de 2015, em cerimônia que contou com a presença do prefeito da Congregação da Causa dos Santos da Santa Sé, o cardeal Angelo Amato, representante do papa Francisco. Disponível em: <http://padrevictor.com.br>. Acesso em: 05 de março de 2017.

10 ofício do delegado de Caldas para o chefe de polícia, 05 de maio de 1887,.APM, Polícia, POL 1 3, cx. 26, doc. 14.

11 Uma das questões que abrem margem para estudos futuros tem a ver com o nível de penetração das ideias acerca da escravidão/abolição no Brasil, proferidas pelos missionários das igrejas presbiterianas do Sul e do Norte. Não nos debruçamos em analisar escritos produzidos por esses missionários, o que contribuiria para entendermos a complexidade dessas ideias em contexto brasileiro. John Boyle, missionário responsável pela conversão dos irmãos Dias, era da porção Sul do país. Sobre estas hipóteses, ver Léonard, 1981: 101; e Matos, 2004: 195-200.

12 os colportores eram responsáveis por vender e distribuir bíblias e folhetos das igrejas, abrindo caminhos para a chegada de missionários que trabalhariam para a conversão da comunidade. Eles eram assistentes no processo de evangelização.

13 História da formação da Igreja Presbiteriana de Cabo Verde. Manuscrito de 25 de outubro de 1912, de Joaquim Leonel de Magalhães, membro presbiteriano. Acervo particular da Igreja Presbiteriana de Cabo Verde-MG.

14 Correspondência recebida pela Presidência da Província, 07 de janeiro de 1887. APM, Polícia, POL 13 , cx. 03, doc. 09.

15 Idem.

16 Gazeta de Notícias, 15 de novembro de 1887, Rio de Janeiro, BN, fl. 02.

17 Correspondência recebida pela Presidência da Província, 07 de janeiro de 1887. APM, Polícia, POL 13 , cx. 03, doc. 09.

18 ofício recebido da delegacia de Cabo Verde, 13 de fevereiro de 1887. APM, Polícia, POL 13, cx.03, doc. 12. 
19 IdemOfício recebido da delegacia de Cabo Verde, 13/02/1887, APM, Polícia, POL 13, cx.03, doc. 12.

20 ofício do delegado de Caldas para o chefe de polícia, 05 de maio de 1887. APM, Polícia, POL 1 3, cX. 26, doc. 14; Correspondência expedida pela Secretaria de Polícia ao Governo Provincial, 21de maio de 1887. APM, Polícia, POL 93, n. 471, fl. 123v.

21 Em geral, nos referimos à tentativa de combate da delegacia de Cabo Verde de conter as movimentações escravas e as ideias de perturbações da ordem pública, como a Correspondência reservada expedida pela Secretaria de Polícia, 22 de novembro de 1887. APM, Polícia, Pol 98, fl. 99; e outros casos, como: Ofício recebido da delegacia de Cabo Verde, 20 de janeiro de 1887. APM, Polícia, POL 13 , cx. 03, doc. 06; Ofício recebido da delegacia de Cabo Verde, 20 de janeiro de 1887. APM, Polícia, POL 13, cx. 03, doc. 07; e a Correspondência expedida pela Secretaria de Polícia ao Governo Provincial, 15 de dezembro de 1887. APM, Polícia, POL 93, ก. 1703.

22 Ofício do advogado Alberto John Monteiro de Barros para o juiz municipal de Cabo Verde e Muzambinho, 14 de abril de 1887. APM, Polícia, POL 13, cx.26., doc. 29.

23 Idem.

24 Liberal Mineiro, 10 de fevereiro de 1883, Ouro Preto, BN, fl.02.

25 Correspondência da Secretaria de Governo para a Secretaria de Polícia, 16 de dezembro de 1887. APM, Polícia, SG 487, n. 536.

26 Monitor Sul-Mineiro, 18 de novembro de 1882, Campanha, CECML, fl. 01.

27 Ibidem, 20 de novembro de 1882, Campanha, CECML, fl. 02.

28 Ibidem, 31 de julho de 1887, Campanha, CECML, fl. 01.

29 Segundo Pereira (1886: 33-39): "Julgavam os Estados do Sul, na América do Norte, que acabar com os escravos era matar o 'rei algodão', destruir a lavoura, e, consequentemente, a riqueza e prosperidade do paiz. No $1^{\circ}$ de janeiro de 1863, um golpe violento do grande Lincoln converte em cidadãos 4 milhões de escravos. Após o terrível abalo, e apesar de 4 annos de tremenda guerra civil, a riqueza e progresso dos Estados Unidos não tem rivaes, e os sulistas em nada têm que invejar a prosperidade do Norte".

\section{REFERÊNCIAS BIBLIOGRÁFICAS}

ABREU, Martha, 0 império do divino. Festas religiosas e cultura popular no Rio de Janeiro, 1830-1900. Rio de Janeiro: Nova Fronteira, 1999.

ALBUQUERQUE, Wlamyra. O jogo da dissimulação. Abolição e cidadania negra no Brasil. São Paulo: Companhia das Letras, 2009.

ALONSO, Angela. Flores, votos e balas. 0 movimento abolicionista brasileiro (1868-88). São Paulo: Companhia das Letras, 2015.

AZEVEDO, Célia Maria. Abolicionismo: Estados Unidos e Brasil, uma história comparada (século XIX). São Paulo: Annablume, 2003.

BRITO, Luciana. Impressões norte-americanas sobre escravidão, abolição e relações raciais no Brasil escravista. 2014. Tese (Doutorado em História Social) - Universidade de São Paulo, São Paulo. 2014. 
CARVALHO, Adilson de. A Freguesia de Nossa Sra. da Assumpção do Cabo Verde e sua história. São Paulo: s/d.

CHARTIER, R. História cultural. Entre práticas e representações. Rio de Janeiro: Bertrand Brasil, 1990.

COSTA, Emília Viotti da. Coroas de glória, lágrimas de sangue. A rebelião dos escravos em Demerara em 1823. São Paulo: Companhia das Letras, 1998.

COTA, Luiz Gustavo. Ave libertas: abolicionismo e luta pela liberdade em Minas Gerais na última década da escravidão. 2013. Tese (Doutorado em História Social) - Universidade Federal Fluminense, Niterói. 2013.

CUSTÓDIO SOBRINHO, Juliano. Sobre um tempo de incertezas: o processo da abolição e os significados da liberdade em Minas Gerais (1880-1888). Curitiba: Ed. CRV, 2018.

DAIBERT JUNIOR, Robert. Isabel, a "Redentora" dos escravos: uma história da princesa entre olhares negros e brancos (1846-1988). Bauru: Edusc, 2004.

DAVIS, David Brion. O problema da escravidão na cultura ocidental. Rio de Janeiro: Civilização Brasileira, 2001.

FERREIRA, Júlio Andrade. O apóstolo de Caldas. Franca: Ribeirão Gráfica e Editora, 2010.

LÉONARD, Émile. O protestantismo brasileiro. São Paulo: Juerp/Aste, 1981.

LESSA, Vicente Themudo. Anais da 1a Igreja Presbiteriana de São Paulo - 1863-1903. Subsídios para a história do presbiterianismo brasileiro. São Paulo: Cultura Cristã, 2010.

LIMA, Lana. Rebeldia negra \& abolicionismo. Rio de Janeiro: Achiamé, 1981.

MANSUR, Alexandre. Luzes e sombras: a ação da maçonaria brasileira (1870-1910). Campinas: Ed. Unicamp, 1999.

MACHADO, Maria Helena Pereira Toledo. O plano e o pânico. Os movimentos sociais na década da abolição. 2. ed. São Paulo: Edusp, 2010.

Os abolicionistas brasileiros e a Guerra de Secessão. In: ABREU, Martha; PEREIRA, Matheus (org.) Caminhos da liberdade: histórias da abolição e do pós-abolição no Brasil. Niterói: PPGHistória-UFF, 2011.

MATOS, Alderi. O Colégio Protestante de São Paulo: um estudo de caso sobre as prioridades da estratégia missionária. Revista Fides Reformada, São Paulo, v. 4, n. 2, 1999.

Pioneiros presbiterianos do Brasil. São Paulo: Cultura Cristã, 2004.

MATTOS, Hebe. Das cores do silêncio. Os significados da liberdade no Sudeste escravista. Rio de Janeiro: Nova Fronteira, 1998.

MENDONÇA, Antônio Gouvêa. O celeste porvir. a inserção do protestantismo no Brasil. São Paulo: Edusp, 2008.

MIRANDA, Amélio de. A história de Três Pontas. Belo Horizonte: Ed. JC, 1980.

MIRANDA, Clícea Maria de. Repercussões da Guerra Civil Americana no destino da escravidão no Brasil 1861-1888. 2017. Tese (Doutorado em História Social) - Universidade de São Paulo, São Paulo. 2017.

MORAES, Evaristo de. A campanha abolicionista: 1879-1888. 2. ed. Brasília: Ed. UnB, 1986.

OILIAM, José. A abolição em Minas. Belo Horizonte: Itatiaia, 1962. 
OLIVEIRA, Ana Maria. O destino (não) manifesto. Os imigrantes norte-americanos no Brasil. São Paulo: União Cultural Brasil-Estados Unidos, 1995.

PEREIRA, Eduardo Carlos. A religião christã em suas relações com a escravidão. São Paulo: Typographia a Vapor de Jorge Seckeler \& c., 1886.

SANTOS, Ronaldo Marcos dos. Resistência e superação do escravismo na Província de São Paulo (18851888). São Paulo: IPE/USP, 1980.

SLENES, Robert. Os múltiplos de porcos e diamante: a economia escravista em Minas Gerais no século XIX. Cadernos IFCH-UNICAMP, Campinas, n. 17, 1985.

SILVA, Hélio. A Igreja Presbiteriana do Brasil e a escravidão: breve análise documental. Revista Fides Reformada, São Paulo, v. 15, n. 2, 2010.

SOARES, Mariza. Devotos da cor: identidade étnica, religiosidade e escravidão no Rio de Janeiro do século XVIII. Rio de Janeiro: Civilização Brasileira, 2000.

VIEIRA, David. O protestantismo, a maçonaria e a questão religiosa no Brasil. 2. ed. Brasília: Ed. UnB, 1980. 